\title{
Determination of T-lymphocyte Subsets in a North African Population (Tunisia): Establishment of Normal Ranges and Results in HIV-Infected Individuals
}

S. Feki ${ }^{1}$, Z. Rekaya ${ }^{1}$, T. Ben Chaaben ${ }^{2}$, A. Zribi ${ }^{2}$, K. Boukef ${ }^{1}$ and F. Jenhani ${ }^{1}$

${ }^{1}$ Laboratoire d'Immunologie Cellulaire, Centre National de Transfusion Sanguine, Tunis, Tunisia

${ }^{2}$ Service Infectieux, Hopital La Rabta, Tunis, Tunisia

KEYWORDS: Lymphocyte subsets, HIV, North Africa

\section{INTRODUCTION}

Human Immunodeficiency Virus (HIV) infection is characterized by a depletion of the CD4+ T-lymphocytes. Absolute counts of CD3+CD4+ cells have been used in monitoring the progression of this disease and in assessing clinical trials of drugs developed to treat HIV infection and related complications [6,10]. In 1993, the definition of AIDS was revised to include HIV-infected persons whose CD4+ Tlymphocytes were $\leq 200$ per $\mu$, even in the absence of opportunistic infections or neoplasm.

Both the CDC (Center for Disease Control) and WHO (World Health Organization) have emphasized the need to study lymphocyte subsets in normal populations [3]. It is thus necessary for a testing laboratory to establish normal ranges for these subsets in its local population. A number of studies have been done on lymphocyte subsets in healthy individuals. There is, however, a paucity of published data about Tunisians and North Africans in general. Therefore, our first objective in the present study was the establishment of normal ranges for $\mathrm{CD} 3+\mathrm{CD} 4+$ and $\mathrm{CD} 3+\mathrm{CD} 8+$ cells in a healthy Tunisian population. After that, the second step was the assessment of lymphocyte subsets in HIV infected individuals.

\section{MATERIALS AND METHODS}

\section{Subjects}

The population studied comprised 52 healthy blood donors of both sexes, aged from 19 to 56, and 53 HIV-1 seropositive patients, also of both sexes and aged from 23 to 57.

\section{Flow cytometric analysis}

Aliquots of blood samples were stained with a panel of TriTEST reagents, using TruCount Absolute Count tubes (Becton Dickinson). Data were collected on the cytometer (FacsCalibur, Becton Dickinson) using MultiSet software.

\section{RESULTS AND DISCUSSION}

Tables 1 and 2 show data on lymphocyte subsets for the healthy donors and the HIV-1 seropositive patients. Among the 53 seropositive 
Table 1

Lymphocyte subsets in percentages for the healthy donors and the HIV-1 seropositive patients

\begin{tabular}{cccccccccc}
\hline & \multicolumn{3}{c}{ Healthy donors } & \multicolumn{3}{c}{ HIV seropositives } & \multirow{2}{*}{$\chi^{2}$} & $\mathrm{p}$ \\
\cline { 2 - 7 } & Average & DS & Min-max & Average & DS & Min-max & & NS \\
CD3+ & 71.8 & 6 & $58-83$ & 75 & 15.8 & $25-94.4$ & 0.0019 & \\
CD3+CD4+ & 43.2 & 7.6 & $29-66$ & 12.3 & 9.25 & $0.244-32$ & 1.7969 & $<10^{-3}$ \\
CD3+CD8+ & 24.1 & 7.6 & $12-40$ & 58.7 & 15.6 & $21.3-98$ & 0.8462 & $<10^{-3}$ \\
CD4:CD8 ratio & 1.93 & 0.8 & $0.72-4.55$ & 0.24 & 0.2 & $0.004-0.9$ & 6.166 & $<10^{-3}$ \\
\hline
\end{tabular}

Table 2

Lymphocyte subsets in absolute counts for the healthy donors and the HIV-1 seropositive patients

\begin{tabular}{ccccccccc}
\hline & \multicolumn{3}{c}{ Healthy donors } & \multicolumn{3}{c}{ HIV seropositives } & \multirow{2}{*}{$\chi^{2}$} & $\mathrm{p}$ \\
& Average & DS & Min-max & Average & DS & Min-max & \multicolumn{2}{c}{ NS } \\
CD3+ & 1345 & 353 & $632-1937$ & 1229 & 400 & $54-4894$ & 0.0081 & NS \\
CD3+CD4+ & 799 & 245 & $388-1597$ & 227 & 309 & $0-1347$ & 1.80 & $<10^{-3}$ \\
CD3+CD8+ & 470 & 202 & $170-1140$ & 840 & 679 & $43-2855$ & 0.346 & $<10^{-3}$ \\
\hline
\end{tabular}

Table 3

Distribution of patients according to their clinico-biological stage (CDC classification; 1993)

\begin{tabular}{ccccr}
\hline $\begin{array}{c}\text { Clinical } \\
\text { category }\end{array}$ & $\begin{array}{c}\text { Number } \\
\text { of patients }\end{array}$ & $\begin{array}{c}\text { Biological } \\
\text { category }\end{array}$ & $\begin{array}{c}\text { Number } \\
\text { of patients }\end{array}$ & $\begin{array}{c}\text { Average of } \\
\text { CD3+CD4+ cells } / \mathrm{mm}^{3}\end{array}$ \\
\hline \multirow{2}{*}{ A } & $2(5.13 \%)$ & A1 & 0 & 0 \\
& & A2 & $2(5.13 \%)$ & 331 \\
& & A3 & 0 & 0 \\
B & B1 & $4(10.3 \%)$ & 991 \\
& \multirow{2}{*}{$17(43.6 \%)$} & B2 & $5(12.8 \%)$ & 291 \\
C & & B3 & $8(20.5 \%)$ & 75 \\
& $20(51.3 \%)$ & C1 & $1(2.56 \%)$ & 591 \\
& & C2 & $2(5.13 \%)$ & 271 \\
\end{tabular}

subjects, 39 are classified according to clinical stage (we have no clinical data for the others), using the CDC classification (1993), and the results are shown on Table 3 .

This report provides data on $\mathrm{CD} 3+$, $\mathrm{CD} 3+\mathrm{CD} 4+$ and $\mathrm{CD} 3+\mathrm{CD} 8+$ lymphocyte counts, and $\mathrm{CD} 4: \mathrm{CD} 8$ ratios, in an HIV seronegative North African (Tunisian) population (Tables 1 and 2). There is little published data of this type.

When we compare these Tunisian normal values to results obtained in other countries, we note that:

Both the percentage and the absolute count of $\mathrm{CD} 3+$ and $\mathrm{CD} 3+\mathrm{CD} 4+$ cells are very similar to those published in French [2], Belgian [7] and
Australian studies [3]. Both the percentage and the absolute count of $\mathrm{CD} 3+\mathrm{CD} 8+$ cells are slightly decreased compared to those obtained in the study of Blanc et al. [2] using the same cytometer mark, the same reagents and the same analysis method, but the differences are not significative.

Finally, when we consider the CD4:CD8 ratio calculated from the percentages of $\mathrm{CD} 3+\mathrm{CD} 4+$ and $\mathrm{CD} 3+\mathrm{CD} 8+$ cells, we note that it is much higher than the value reported by Hannet et al. [7] (average $=1.2 ; \min =1 ; \max =1.5$ ) and could be explained by the high CD8+ value in this Belgian study. 
Comparing HIV seronegative patients with HIV seropositive subjects, the latter group has significantly lower percentages and numbers of CD $3+$ CD4 + cells $\left(p<10^{-3}\right)$, higher numbers of CD $3+$ CD $8+$ cells $\left(p<10^{-3}\right)$ and a lower CD4:CD8 ratio $\left(\mathrm{p}<10^{-3}\right)$. There is no difference in the percentage and the number of CD3+ cells between these two groups.

These results are in accord with those obtained all over the world. The depletion of CD3+CD4+ cells is not clearly explained at present; however, an increase of the CD3+CD8+ cells is explained by expansion of the cytotoxic T-lymphocyte population during HIV infection.

We used, in our laboratory, the CD38 marker in a two-stain combination with CD8, in HIV seropositive samples, and we found that nearly all of the $\mathrm{CD} 3+\mathrm{CD} 8+$ cells were $\mathrm{CD} 38$ positive, concluding that these cytotoxic T-lymphocytes were activated, most probably by the virus.

Considering the distribution of HIV seropositive patients according to their clinicobiological stage (CDC classification; 1993), we note that the majority of patients are in the second (43.6\%) and the third (51.3\%) clinical categories (B and $\mathrm{C}$ ), and most of them are in the third biological category $(20.5 \% \mathrm{~B} 3 ; 43.6 \% \mathrm{C} 3)$. The paucity of subjects of the first clinical category (A) in our data can be explained by the fact that the HIV seropositive patients are diagnosed late, and when they come to our laboratory for a T-lymphocytes subsets count, they are already at the B or C category. The lack of antiretroviral medicines and the natural progression of the disease also explain the bigger number of patients in the third biological categories with an average number of 75 $\mathrm{CD} 3+\mathrm{CD} 4+\mathrm{cell} / \mathrm{mm}^{3}$ for the $20.5 \%$ patients (B3 category) and $57 \mathrm{CD} 3+\mathrm{CD} 4+$ cell $/ \mathrm{mm}^{3}$ for the $43.6 \%$ patients (C3 category).

\section{CONCLUSION}

In Tunisia, HIV infection is relatively not extensive: among the 10 million inhabitants, the total number of declared seropositive individuals since the beginning of the epidemic until now, is one thousand $(0.01 \%)$; two hundred of them have AIDS and every year, there is a mean of 46 new declared cases. HIV infection is not a major problem for Public Health in Tunisia, ahead of other pathologies like hepatitis or cancers. However, the extent of the epidemic in the world causes us to be worried about the future. Therefore, we started in our laboratory by establishing normal ranges for T-lymphocytes subsets counts that could be a reference for all North Africa. Following this, we can monitor the efficacy of treatment available to our patients.

\section{References}

[1] Aboulker, J.P., Autran, B., Beldjord, K., et al. Consistency of routine measurements of CD4+, CD8+ peripheral blood lymphocytes. J. of Immunol. Meth. 154, (1992) 155-161.

[2] Blanc, C., Carcelain, G., Peries L., et al. Intérêt de la numération absolue par cytométrie en flux et du quadruple marquage des sous-populations lymphocytaires lors de l'infection par le VIH. Revue française des laboratoires, octobre 1996, $\mathrm{N}^{\circ} 287$.

[3] Bryant, J.A., Wylie, B.R., Yuan, F.F., et al. Effect of blood donation on the establishment of normal ranges of lymphocytes subsets. Transfusion 36, (1996) 559-566.

[4] Carcelain, G., Blanc, C., Debre, P., et al. Intérêt de l'analyse en cytométrie en flux des souspopulations lymphocytaires chez les patients infectés par le VIH. Revue française des laboratoires, octobre 1996, $\mathrm{N}^{\circ} 287$.

[5] Daniel, V., Süsal, C., Weiner, R., et al. CD8+ lymphocytes decrease in HIV disease: association with anti-CD8+ lymphocyte autoantibodies. Vox Sanguinis 70, (1996) 86-91.

[6] Fishl, M.A., Richman, D.D., Grieco, M.H., et al. The efficacy of azidothymidine (AZT) in the treatment of patients with AIDS and AIDSrelated complex. A double-blind, placebocontrolled trial. N. Eng. J. of Med. 317, (1987) 185-191.

[7] Hannet, I., Erkeller-Yuksel, F., Lydyard, P., et al. Developmental and maturational changes in human blood lymphocyte subpopulations. Immunol. Today 13(6) (1992).

[8] Levin, A., Brubaker, G., Shao, J.S., et al. Determination of T-lymphocyte subsets on site in 
rural Tanzania: results in HIV-1 infected and non-infected individuals. Int. J. of STD \& AIDS 7, July 1996.

[9] Métézeau, P., Miglierina, R. and Ratinaud, M.-H. La cytométrie en flux. PULIM - 1994.

[10] Schwartz, K., Visscher, B., Detels, R., et al. Immunological changes in lymphadenopathy virus positive and negative symptomless male homosexuals: two years of observation. Lancet ii, (1985) 831.

[11] Strauss, K., Hannet, I., Hulstaert, F., et al. Suivi des patients $\mathrm{VIH}+$ et surveillance de leur système immunitaire. «Clinical Notes» de Becton Dickinson. 


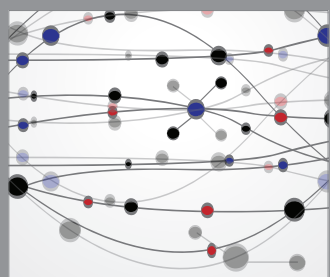

The Scientific World Journal
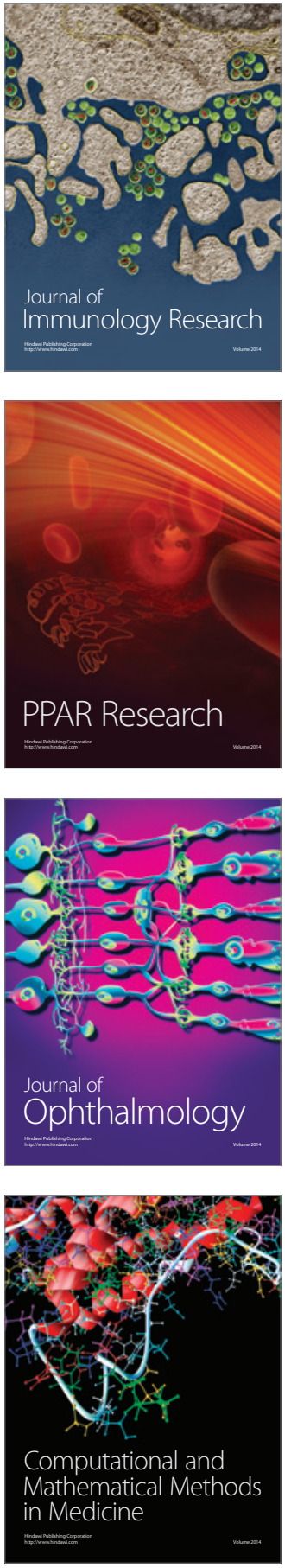

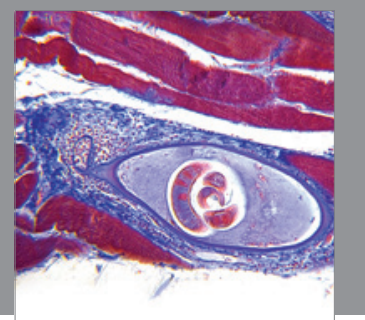

Gastroenterology

Research and Practice
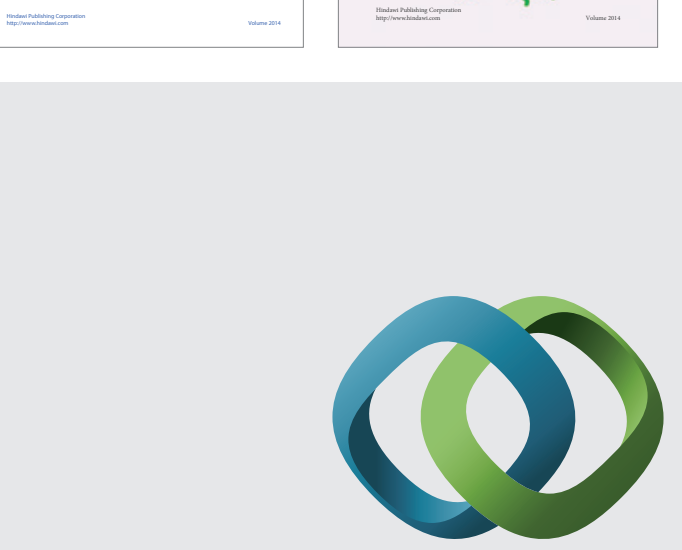

\section{Hindawi}

Submit your manuscripts at

http://www.hindawi.com
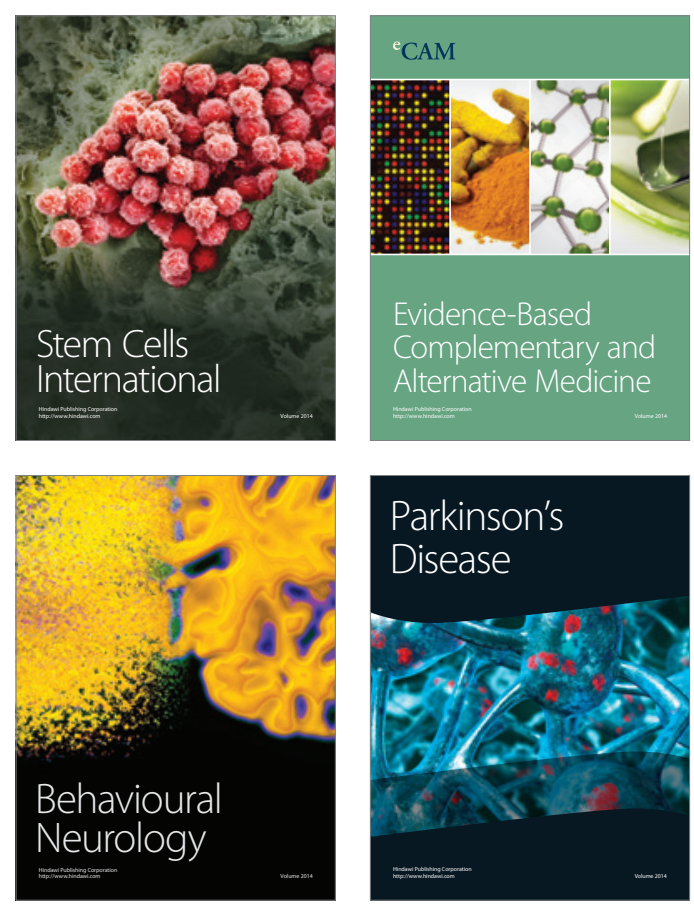

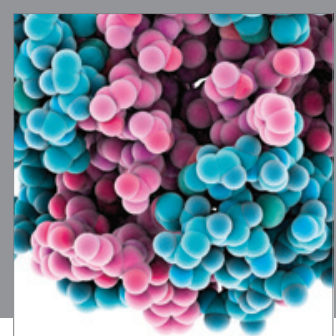

Journal of
Diabetes Research

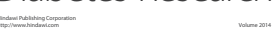

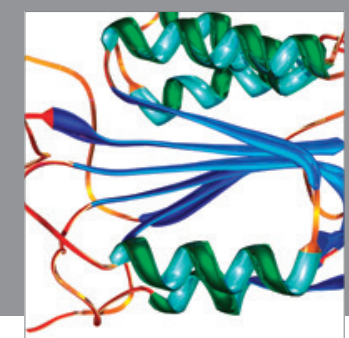

Disease Markers
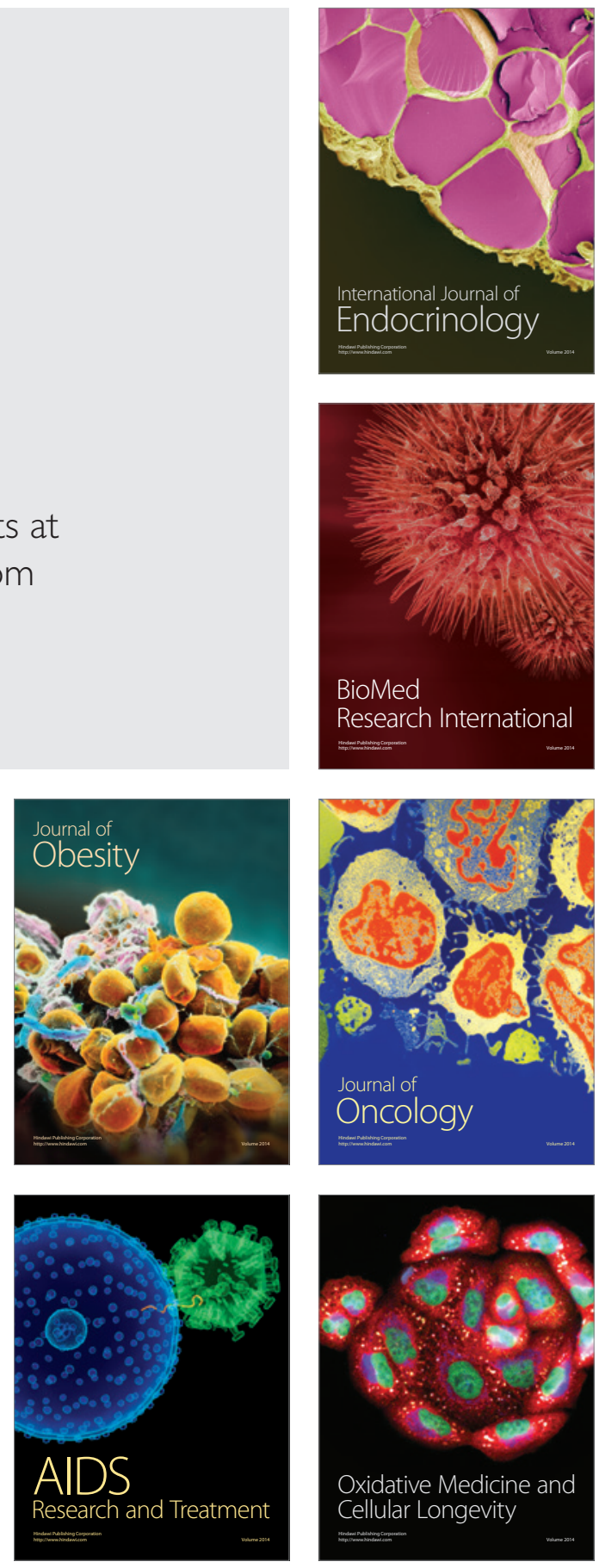